\title{
BENEFITS VARIATION TEACHING STYLE USING METHOD SIMULATION IN LEARNING IPS IN CLASS VI S D NEGERI 17 BATU KUNIT JURAI DISTRICT IV ACADEMIC YEAR 2014/2015
}

\author{
LILI ERVO
}

Volume 1 Nomor 1

JIPS ISSN: 2579-5449

\begin{abstract}
Low student learning outcomes in these days can also be caused by the condition and mental development of students. Basic Education aims to provide the basic ability for learners to develop kehidupannva as private, community members, citizens, and as human beings and to prepare learners to follow the next education in social studies.

To solve the above problems researchers tried a simulation method in teaching social studies education in SDN No. 17 Stone Kunit the District IV Jurai Regency South Coast of the Academic Year 2014/2015. By using simulation method is expected to encourage the participation of students, enhancing skills - skills, decision making, utilize the resources associated with the decision - a decision that would be made, to help develop students' attitudes, develop persuasion and communication as well as introducing students to the role of leadership.

The general objective of this research is to improve the learning process in the sixth grade social studies education No. 17 Stone Kunit the District IV Jurai Regency of South Pesisir in the school year 2014/2015, by using simulation methods with the aim to eliminate boredom, creates excitement, motivation, improve outcomes and the learning process and critical thinking for students.

Implementation of Class Action Research conducted in SDN No. 17 Stone Kunit the District IV Jurai Regency South Coast of the Academic Year 2014/2015. Subject

pemelitian is the number of learners Class VI SDN No. 17 Stone Kunit in the school year 2014/2015 amounted to 22 students. Scores obtained by the students in the first cycle is still far below the standard. The average value of the first cycle is a pre-test of 5.16 and 5.99 pe test. Increased 0.83 . students who earn top grades 6 to 17 people $(51.51 \%)$. Meanwhile, students who scored less than 6 there were $16(48.49 \%)$.

Based on the analysis of student work in the second cycle also showed an increase in that of the average scores of post test increased to $5.99,6.43$ so there is an increase of 0.44 . In the second cycle students who scored 6 and above there are 15 people, and students who scored less than 6 No 7 of the number of students 22 people. Based on the analysis of work of students in the third cycle in general learning results obtained by the students showed an increase.

This we compare a score of 5.99, 6.43 second cycle and the third cycle becomes 7.12 of unity cycle up 0.44 kesiklus second and third cycle of unity kesiklus 0.69 . The number of students who received a score of 6 and 19 and learners who score below 6 No 3 number of students 22 people.

In general, the process of learning social studies using simulation methods can improve results and get a positive response from the majority of students of class VI SDN No. 17 Stone Kunit K ecamatan IV Jurai Regency South Coast of the Academic Year 2014/2015.
\end{abstract}

Keywords: teaching style , method simulation 


\title{
MANFAAT VARIASI GAYA MENGAJAR DENGAN MENGGUNAKAN METODE SIMULASI PADA PEMBELAJARAN IPS DI KELAS VI SD NEGERI NO.17 BATU KUNIT KECAMATAN IV JURAI TAHUN PELAJARAN 2014/2015
}

\begin{abstract}
ABSTRAK
Rendahnya hasil belajar siswa pada akhir-akhir ini bisa juga diakibatkan oleh kondisi dan perkembangan mental murid. Pendidikan Dasar bertujuan untuk memberikan kemampuan dasar kepada peserta didik untuk mengembangkan kehidupannva sebagai pribadi, anggota masyarakat, warga negara, dan sebagai umat manusia serta mempersiapkan peserta didik untuk mengikuti pendidikan yang berikutnya dalam mata pelajaran IPS.

Untuk memecahkan persoalan di atas peneliti mencoba menggunakan metoda simulasi dalam pembelajaran pendidikan IPS di SDN No. 17 Batu Kunit Kecamatan IV Jurai Kabupaten Pesisir Selatan Tahun Pelajaran 2014/2015. Dengan menggunakan metoda simulasi diharapkan dapat mendorong partisipasi peserta didik, mempertinggi keterampilan keterampilan, membuat keputusan, memanfaatkan sumber-sumber yang berhubungan dengan keputusan - keputusan yang hendak dibuat, membantu mengembangkan sikap siswa, mengembangkan persuasi dan komunikasi serta memperkenalkan kepada siswa tentang peranan kepemimpinan.

Secara umum tujuan dari penelitian ini adalah untuk memperbaiki proses pembelajaran pada pendidikan IPS di kelas VI No. 17 Batu Kunit Kecamatan IV Jurai Kabupaten Pesisir Selatan Tahun Pelajaran 2014/2015, dengan menggunakan metode simulasi dengan tujuan menghilangkan kejenuhan, menciptakan kegembiraan, menumbuhkan motivasi, meningkatkan hasil dan proses pembelajaran serta berpikir kritis bagi peserta didik.

Pelaksanaan Penelitian Tindakan Kelas dilakukan di SDN No. 17 Batu Kunit Kecamatan

Pelajaran 2014/2015. Subjek pemelitian adalah jumlah peserta didik kelas VI SDN No. 17 Batu Kunit Tahun Pelajaran 2014/2015 berjumlah 22 orang siswa.Skor yang diperoleh siswa pada siklus pertama ini masih jauh di bawah standar. Nilai rata-rata pada siklus pertama adalah pre tes 5,16 dan pe tes 5,99 . Meningkat 0,83 . siswa yang mendapatkan nilai 6 ke atas ada 17 orang $(51,51 \%)$. Sedangkan siswa yang mendapatkan nilai kurang dari 6 ada 16 orang $(48,49 \%)$.

Berdasarkan hasil analisis pekerjaan siswa pada siklus kedua ini juga menunjukkan adanya peningkatan yaitu dari sekor rata-rata post tes 5,99 naik menjadi, 6,43 sehingga ada peningkatan 0,44. Pada siklus kedua siswa yang mendapat nilai 6 keatas ada 15 orang, dan siswa yang mendapat nilai kurang dari 6 ada 7 orang dari jumlah siswa 22 orang. Berdasarkan hasil analisis pekerjaan peserta didik pada siklus ketiga ini pada umumnya hasil belajar yang diperoleh peserta didik menunjukkan adanya peningkatan.

Hal ini kita bandingkan dari skor 5,99, siklus kedua 6,43 dan pada siklus ketiga menjadi 7,12 dari siklus kesatu kesiklus kedua naik 0,44 dan dari siklus kesatu kesiklus ketiga 0,69. Banyaknya peserta didik yang mendapat nilai 6 dan 19 orang dan peserta didik yang mendapat nilai dibawah 6 ada 3 orang jumlah siswa 22 orang.

Secara umum proses pembelajaran IPS dengan menggunakan metode simulasi dapat meningkatkan hasil dan mendapatkan tanggapan yang positif dari sebagian besar siswa kelas VI SDN No. 17 Batu Kunit Kecamatan IV Jurai Kabupaten Pesisir Selatan Tahun Pelajaran 2014/2015.
\end{abstract} IV Jurai Kabupaten Pesisir Selatan Tahun

Kata Kunci : gaya mengajar, metode simulasi 


\section{LATAR BELAKANG}

Berdasarkan pengamatan dan penilaian secara langsung, bahwa pendidikan IPS merupakan salah satu mata pelajaran di Sekolah Dasar yang bagi sebagian siswa terasa membosankan, kurang menarik dan cenderung monoton. Pendidikan IPS merupakan mata pelajaran yang sangat tegas dan berupa hapalanhapalan serta ruang lingkup yang dipelajarannya adalah manusia sebagai anggota masyarakat, gejala dan masalah sosial serta peristiwa tentang kehidupan manusia di masyarakat. Oleh karena itu siswa dituntut untuk lebih memiliki minat yang penuh dan sungguh - sungguh untuk mempelajarinya.

Dalam pelaksanaan evaluasi, pengajaran IPS bagi siswa SDN No. 17 Batu Kunit Kecamatan IV Jurai Kabupaten Pesisir Selatan Tahun Pelajaran 2014/2015 yang rajin dan berminat untuk mempelajarinya, mereka akan lebih mudah dalam mengerjakan dan memecahkan soal yang dihadapinya dan mereka akan menggemari pelajaran IPS karena IPS bukan merupakan pelajaran eksak atau ilmu pasti yang memerlukan satu jawaban yang pasti. Kenyataan yang ada pada masa sekarang ini, ternyata kemajuan tekhnologi melahirkan dua sisi yaitu sisi positif dan sisi negatif. Dengan banyaknya media visual yang menayangkan berbagai macam sajian berupa tontonan maupun permainan - permainan sehingga minat baca siswa menjadi berkurang bahkan sangat kurang. Mereka lebih sutra menghabiskan waktunya untuk menonton televisi dan video game. Selain itu guru - guru masih belum dapat memanfaatkan secara maksimal berbagai metode yang tepat untuk mendapatkan hasil yang memuaskan sehingga dampaknya hasil pembelajaran Pendidikan IPS di Sekolah Dasar sangat rendah.

Rendahnya hasil belajar siswa pada akhir-akhir ini bisa juga diakibatkan oleh kondisi dan perkembangan mental murid. "Kemampuan mental anak didik sesuai dengan tingkat umur dan pengalamannya berkembang mulai dari tingkat umur atau tingkat pendidikan yang rendah menuju kearah kematangan. Oleh karena itu bobot luas pendalaman materi IPS yang diajarkan harus disesuaikan dengan kemampuan murid. " Pendidikan merupakan usaha sadar untuk menyiapkan peserta didik melalui kegiatan bimbingan, pengajaran dan latihan bagi peranannya di masa yang akan datang.

Dengan adanya pendidikan diharapkan peserta didik akan memiliki kemampuan dan kepribadian yang berkembang. Pendidikan Nasional berfungsi mengembangkan dan membentuk watak serta peradaban bangsa yang bermartabat dalam rangka mencerdaskan kehidupan bangsa, bertujuan untuk berkembangnya potensi peserta didik agar menjadi manusia yang beriman dan bertakwa kepada Tuhan Yang Maha Esa; berakhlak mulia, sehat, berilrru, cakap, kreatif, mandiri dan menjadi warga negara yang demokratis serta bertanggung jawab (UU RI No 20 tahun 2003 tentang SISDIKNAS).

Pendidikan Dasar bertujuan untuk memberikan kemampuan dasar kepada peserta didik untuk mengembangkan kehidupannva sebagai pribadi, anggota masyarakat, warga negara, dan sebagai umat manusia serta mempersiapkan peserta didik untuk mengikuti pendidikan yang berikutnya. Pendidikan Dasar harus selalu menyelaraskan dan mengantisipasi perubahan agar materi dan pengalaman belajar dalam proses belajar mengajar -yang diberikan di Sekolah Dasar berguna untuk bekal kehidupannya.Fungsi sekolah harus membantu mewujudkan kemandirian bagi peserta didik dalam arti melek huruf, melek tekhnologi dan melek pikiran (Semiawan. C 1992: 12).

Dalam Garis - Garis Besar Program Pengajaran (GBPP) IPS, bahwa tujuan umum mata pelajaran IPS pada jenjang pendidikan dasar yaitu : 1) Mata pelajaran Ilmu Pengetahuan Sosial di SD bertujuan agar siswa mampu mengembangkan pengetahuan dan keterampilan dasar yang berguna bagi dirinya dalam kehidupan sehari hari. 2) Pengajaran IPS yang bertujuan agar siswa mampu mengembangkan pemahaman tentang perkembangan masyarakat Indonesia sejak masa lalu hingga masa kini sehingga siswa memiliki kebanggaan sebagai bangsa Indonesia dan cinta tanah air.

Sasaran pokok pembelajaran pendidikan 1PS di Sekolah Dasar adalah sebagai berikut : 1) Mengenalkan kepada siswa tentang hubungan antara manusia dengan lingkungan hidupnya. 2) Memberikan pengetahuan agar siswa memahami peristiwa-peristiwa serta perubahan yang terjadi disekitarnya. 3) Mengembangkan kemampuan siswa untuk mengenal kebutuhan - kebutuhannya serta menyadari bahwa manusia lain pun memiliki kebutuhan. 4) Menghargai kebudayaan 
masyarakat sekitarnya, bangsa juga budaya bangsa lain. 5) Memahami dan menerapkan prinsip-prinsip ekonomi yang bertalian dengan dirinya sendiri maupun dengan bangsa lain di dunia. 6) Memahami bahwa antar manusia yang satu dengan lainnya saling membutuhkan serta dapat menghormati harkat dan nilai manusia. 7) Memahami dan bertanggung jawab dalam pemeliharaan pemantapan dan pengelolaan sumber daya manusia dan sumber daya alam. 8) Memupuk rasa tanggung jawab terhadap pekerjaan dan hasilnya serta menghargai setiap jenis pekerjaan maupun hasil pekerjaan yang dilakukan orang lain. 9) Memahami dan menghargai IPS bangsanya serta hak-haknya sebagai manusia yang hidup di suatu negara yang merdeka. (Sumaatmadja, N halaman 13).

Hasil observasi tentang proses pembelaiaran terdapat beberapa persoalan yang berkembang terutama mengenai permasalahan yang dialami guru dan siswa dalam pencapaian tujuan pembelajaran. Permasalahan bagi guru diantaranya kesulitan memilih metode yang tepat dan benar, kesulitan merubah minat siswa terhadap pelajaran IPS dan pembelajaran IPS hasilnya masih memperoleh rata - rata rendah. Adapun pemasalahan bagi siswa diantaranya adalah siswa merasa tidak senang terhadap mata pelajaran IPS, siswa kesulitan dalam menangkap pelajaran IPS dan siswa kurang paham serta mendapat nilai yang kurang, dalam mata pelajaran IPS.

Untuk memecahkan persoalan di atas peneliti mencoba menggunakan metoda simulasi dalam pembelajaran pendidikan IPS di SDN No. 17 Batu Kunit Kecamatan IV Jurai Kabupaten Pesisir Selatan Tahun Pelajaran 2014/2015. Dengan menggunakan metoda simulasi diharapkan dapat mendorong partisipasi peserta didik, mempertinggi keterampilan keterampilan, membuat keputusan, memanfaatkan sumber-sumber yang berhubungan dengan keputusan - keputusan yang hendak dibuat, membantu mengembangkan sikap siswa, mengembangkan persuasi dan komunikasi serta memperkenalkan kepada siswa tentang peranan kepemimpinan.
Rumuskan sebagai berikut : Bagaimana hasil belajar siswa kelas VI SDN No. 17 Batu Kunit Kecamatan IV Jurai Kabupaten Pesisir Selatan Tahun Pelajaran 2014/2015, sebelum guru menggunakan metode simulasi ? 2) Apakah penerapan metode simulasi dapat meningkatkan prestasi siswa SDN No. 17 Batu Kunit Kecamatan IV Jurai Kabupaten Pesisir Selatan Tahun Pelajaran 2014/2015, dari prestasi sebelumnya ? 3) Apakah penerapan metode simulasi dapat menyebabkan siswa-siswa lebih senang dalam belajar IPS ? 4) Bagaimana kelebihan dan kekurangan metode simulasi dalam pembelajaran IPS dengan menggunakan metode simulasi di SDN No. 17 Batu Kunit Kecamatan IV Jurai Kabupaten Pesisir Selatan Tahun Pelajaran 2014/2015 ?

Tujuan Penelitian Tindakan Tujuan umum, secara umum tujuan dari penelitian ini adalah untuk memperbaiki proses pembelajaran pada pendidikan IPS di kelas VI SD N No. 17 Batu Kunit Kecamatan IV Jurai Kabupaten Pesisir Selatan Tahun Pelajaran 2014/2015, dengan menggunakan metode simulasi dengan tujuan menghilangkan kejenuhan, menciptakan kegembiraan, menumbuhkan motivasi, meningkatkan hasil dan proses pembelajaran serta berpikir kritis bagi peserta didik.

Tujuan khusus 1) Untuk mengetahui hasil belajar siswa sebelum menggunakan metode simulasi di kelas VI SDN No. 17 Batu Kunit Kecamatan IV Jurai Kabupaten Pesisir Selatan Tahun Pelajaran 2014/2015. 2) Unik mendeskripsikan adakah peningkatan prestasi belajar siswa setelah menggunakan metode simulasi di SDN No. 17 Batu Kunit Kecamatan IV Jurai Kabupaten Pesisir Selatan Tahun Pelajaran 2014/2015. 3) Untuk mendeskripsikan adakah minat siswa dalam pembelajaran IPS dengan menggunakan metode simulasi di SDN No. 17 Batu Kunit Kecamatan IV Jurai Kabupaten Pesisir Selatan Tahun Pelajaran 2014/2015. 4) Untuk mengetahui kelebihan dan kekurangan pembelajaran IPS dengan penerapan metode sirlulasi di SDN No. 17 Batu Kunit Kecamatan IV Jurai Kabupaten Pesisir Selatan Tahun Pelajaran 2014/2015. 


\section{METODOLOGI PENELITIAN}

Jenis Penelitian Penelitian ini adalah Penelitian Tindakan Kelas (PTK) dengan menggunakan model Kemmis dan MC. Taggart (1988). Yang mana Kemmis mengembangkan modelnya berdasarkan sistem spiral refleksi diri yang dimulai dengan rencana, tindakan, pengamatan, refleksi, perencanaan kembali merupakan dasar untuk suatu ancang - ancang pemecahan masalah (Kasihani Kasbalah E. S; 2000: 13).

\section{Penelitian Kurt Lewin dapat digambarkan sebagai berikut:}

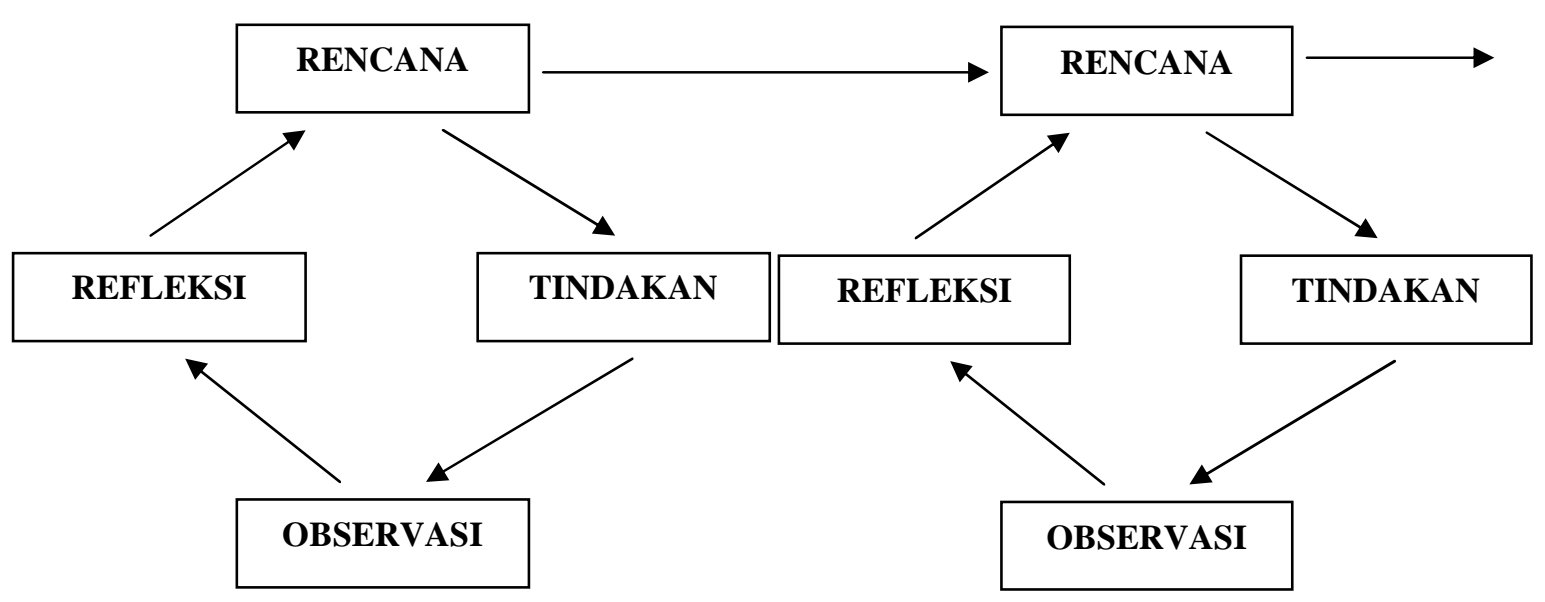

Gambar 3.1

Tahapan Penelitian Tindakan (Kurt Lewin, 1992 : 147)

Prosedur yang digunakan dalam penelitian ini adalah model siklus (Cycle). Setiap siklus tidak hanya berlangsung satu kali, melainkan beberapa kali sampai tercapainya tujuan yang diinginkan. Pada tahap-tahap dalam siklus dilaksanakan peneliti dan guru sudah melibatkan diri secara aktif dari intensif dalam rangkaian kegiatan penelitian. Model siklus yang digunakan dalam penelitian ini berbentuk spiral seperti yang dikembangkan oleh Kemmis dan Taggart (Kasbolah, 1988 : 13) yang meliputi perencanaan, pelaksanaan, pengawasan (observe) dan refleksi.

Kemudian pada siklus berikutnya kegiatan peneliti pada dasarnya sama, tapi adanya modivikasi dan koreksi pada setiap tahapnya. Siklus kegiatan dapat digambarkan sebagai berikut : 


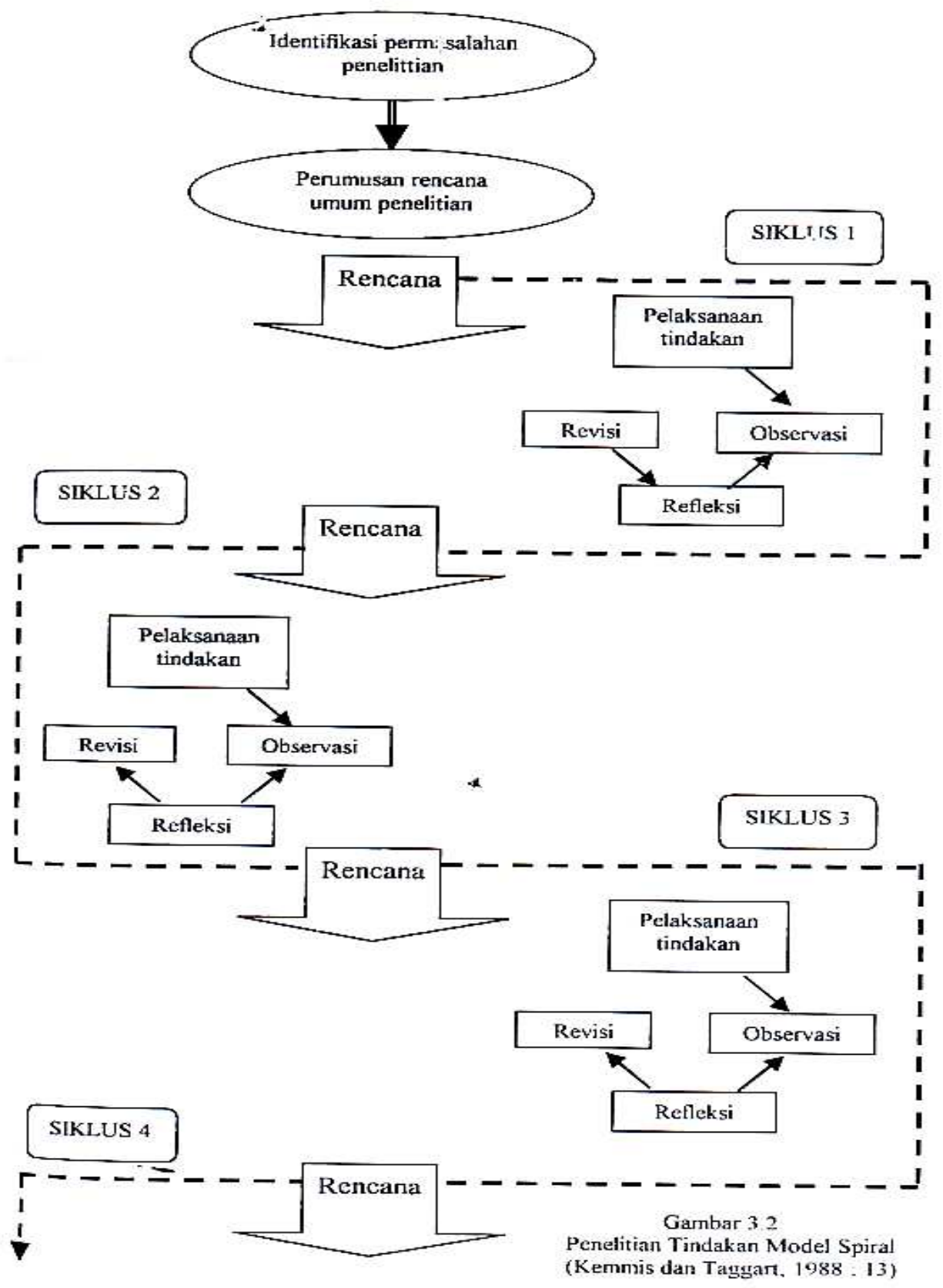

Secara rinci tahap - tahap kegiatan penelitian dalam setiap siklus Langkah-langkah siklus sebagai berikut :

1. Perencanaan

Tahapan perencanaan dimulai dengan konfirmasi ide penelitian kepada kepala sekolah dan para guru, terutama guru kelas VI yang kelasnya dipergunakan sebagai penelitian. Setelah diperoleh kesepakatan tentang masalah penelitian, lalu ditindaklanjuti dengan observasi pelaksanaan pembelajaran di kelas dan wawancara dengan rekan - rekan guru. Kegiatan selanjutnya adalah menyusun rencana tindakan yang akan dilakukan oleh guru sekaligus peneliti yang meliputi : penyusunan skenario pembelajaran dan persiapan alat - alat observasi yang diperlukan. 
Data awal yang diperlukan dalam penelitian ini peneliti melihat langsung dari data hasil ulangan yang sudah terdokumentasi yang ada pada daftar nilai yang diperoleh dari guru wali kelas VI. Tetapi untuk lebih spesifik pada data awal disusun rencana pembelajaran dari pokok bahasan tertentu tetapi belum menerapkan metode simulasi. Dari data awal dapat diketahui kondisi siswa di kelas VI. Tahapan penelitian : 1) Tahap Pelaksanaan Tindakan 2) Tahap Observasi 3) Tahap Refleksi

Instrumen Penelitian a) Observasi, digunakan untuk mengamati proses pembelajaran siswa dan tindakan guru dengan menggunakan metode simulasi pada pembelajaran Pendidikan IPS. Proses pembelajaran yang diamati diantaranya aktivitas siswa dan aktiuitas guru. B) Wawancara, digunakan untuk mengetahui lebih jauh persepsi siswa tentang pembelajaran Pendidikan IPS dengan menggunakan metode simulasi. C) Tes hasil belajar, digunakan untuk mengetahui peningkatan hasil belajar siswa khususnya penguasaan materi pada pembelajaran Pendidikan IPS dengan menggunakan metode simulasi.

Temuan - temuan data - data penelitian diinterpretasikan dengan merujuk pada landasan teoritik, aturan - aturan yang bernilai baik berdasarkan peneliti tentang penerapan metode simulasi pada proses pembelajaran Pendidikan IPS sehingga diperoleh suatu proses pembelajaran yang baik dan bermakna.

\section{HASIL PENELITIAN TINDAKAN}

Berdasarkan data absensi, jumlah peserta didik kelas VI SDN No. 17 Batu Kunit Kecamatan IV Jurai Kabupaten Pesisir Selatan Tahun Pelajaran 2014/2015 berjumlah 22 orang. Dari 22 peserta didik ini terdapat 8 peserta didik yang tergolong lambat belajar. Hal ini disebabkan oleh : a) Kurang berkonsentrasi dalam menerima pelajaran. b) Masih sering bermain dan ngobrol di kelas.

Silklus Pertama Untuk melaksanakan siklus pertama dalam proses pembelajaran peneliti menyusun perencanaan yang mencakup : 1) Penyusunan rancangan pembelajaran 2) Pembentukan kelompok 3) Merumuskan masalah. Format penyusunan rancangan pembelajaran meliputi : 1) Bidang studi 2) Pokok bahasan 3) Sub pokok bahasan 4) Kelas / semester 5) Waktu 6) Hari / Tanggal 7) Tujuan Pembelajaran Umum 8) IL Tujuan Pembelaiaran Khusus 9) Materi Pelajaran 10) Metode, Media Dan Sumber 11) Kegiatan Pembelajaran 12) Evaluasi.

Pembentukan kelompok dibuat agar adanya keseimbangan pada tiap - tiap kelompok dengan adanya keragaman siswa dari jenis kelamin, prestasi belajar siswa dan aktivitas siswa untuk dapat bekerja sama dalam menyelesaikan suatu pennasalahan. . Untuk meningkatkan motivasi siswa, setiap kelompok diberi nama bunga. Nama - nama kelompok tersebut adalah kelompok mawar, kelompok melati, kelompok bunga matahari, kelompok anggrek, kelompok dahlia dan kelompok tulip.

Berdasarkan hasil analisis dan refleksi dari proses pembelajaran masalah yang akan di kaji oleh siswa pada siklus I adalah sebagai berikut : 1) Apa yang di maksud dengan sumber daya alam ? 2) Jelaskan apa yang di maksud dengan Sumber daya alam yang dapat diperbaharui ! 3) Apa yang di maksud dengan flora dan fauna?

Refleksi Siklus Pertama Berdasarkan proses observasi pada pembelajaran siklus pertama ini proses pembelajaran dengan menggunakan pencapaian metode simulasi, masih memiliki berbagai kekurangan. Diantara pengelola alokasi waktu masih belum efektif dengan adanya kelebihan penggunaan waktu dari alokasi waktu yang telah ditentukan. Yaitu pada waktu kegiatan ini (permainan simulasi) dalam memberikan tanggapan-tanggapan yang terlalu lama.

Kemudian dalam memberikan tanggapan masih ada siswa yang menjawab dengan ragu-ragu, dan ada juga yang menjawab dengan bantuan temannya, dan jika penentu langkah jatuh pada nomor yang tertera pada gambar bintang karena harus menyanyi siswa masih memilih lagu apa yang harus dinyanyikan walaupun sudah ditentukan yaitu guru meminta menyanyikan lagu wajib. Pada waktu membacakan pesan - pesan yang tertera dalam beberan simulasi masih ada siswa yang kurang lantang dan kurang jelas sehingga tidak dapat dipahami oleh pemain utama yang lainnya maupun oleh penonton atat peserta, sehingga peserta sulit untuk memberikan tanggapannya dan akhirnya dibaca berulang - ulang. 


\section{Jurnal Ilmiah Pendidikan Scholastic}

Dan masih ada siswa sebagai pemain utama merasakar kesulitan untuk memberikan tanggapan terhadap pesan - pesan yang diperolehnya. Pelaksanaan kerja kelompok belum dapat berjalan secara optimal. Hal in terlihat dalam pengerjaan LKS masih ada beberapa anggota kelompok yanl bekerja secara individual. Ada anggota yang pasif artinya memperhatikan LKS tetapi tidak memberikan tanggapan apapun. Hal ini menunjukkan masih belum solidnya kerja sama antara sesama anggota kelompok. Hasil analisis evaluasi pada siklus pertama menunjukkan bahwa masih ada siswa yang menjawab soal persis dengan pertanyaan yang tertera pada lemba evaluasi tersebut.

Skor yang diperoleh siswa pada siklus pertama ini masih jauh di bawah standar. Nilai rata-rata pada siklus pertama adalah pre tes 5,16 dan pe tes 5,99 . Meningkat 0,83 . siswa yang mendapatkan nilai 6 ke atas ada 15 orang $(51,51 \%)$. Sedangkan siswa yang mendapatkan nilai kurang dari 6 ada 56 orang $(48,49 \%)$. Jumlah siswa 22 orang tetapi tidak hadir 2 orang. Untuk mengetahui nilai hasil evaluasi pada siklus pertama ini dapat di lihat pada tabel 4.5

Siklus kedua Siklus kedua dilaksanakan sebanyak satu kali pertemuan. Proses pembelajaran siklus kedua ini sama dengan siklus pertama yaitu dengan pokok bahasan yang sama tetapi dengan sub pokok bahasan yang berbeda. Pada siklus kedua sub pokok bahasan yang dipilih adalah sumber daya alam yang tidak dapat diperbarui. Langkah awal pada siklus kedua adalah guru memberikan lembaran soal pre tes kepada seluruh peserta didik.

Setelah peserta didik selesai mengerjakan soal-soal pretes lalu guru mengadakan apersepsi dan memberikan petunjuk-petunjuk dalam permainan simulasi yang akan membahas sub pokok bahasan yang baru, supaya permainan simulasi lebih bermakna dan pada permainan simulasi yang pertama. Langkah selanjutnya adalah permainan simulasi yang dimainkan oleh kelompok matahari dan kelompok anggrek. Pada simulasi siklus kedua ini peserta didik lebih tertib dan lebih berani dalam memberikan tanggapan-tanggapan pada setiap pesan yang tertera pada beberapa simulasi, walaupun jawabannya masih kurang sempurna. Peserta atau penonton dalam memberikan tanggapannya lebih banyak dan lebih cepat jika dibandingkan pada siklus pertama, tetapi masih ada yang tidak memberikan tanggapan dan hanya diam saja, atau kurang memperhatikan pesan apa yang dibacakan temannya sebagai pemain utama simulasi. Pada kegiatan berikutnya guru membagikan LKS pada tiap - tiap kelompok yang telah dibentuk pada siklus pertama.

Sebelum mengisi LKS guru terlebih dahulu memberikan pengarahan dan penunjuk baik dalam kerja kelompok maupun dalam menyelesaikan tugas yang ada pada LKS ,supaya tiap-tiap kelompok dapat bekerja dengan baik. Sebagai kegiatan akhir guru memberikan kesimpulan tentang materi yang telah dibahas oleh peserta didik yaitu sumber daya alam yang tidak dapat diperbarui.

Refleksi siklus kedua Proses pembelajaran dan hasil belajar pada siklus kedua ini pada umumnya mengalami peningkatan dari siklus pertama, namun peningkatannya belum mencapai maksimal. Kegiatan peserta didik lebih aktif, baik dalam pelaksanaan simulasi maupun dalam pelaksanaan kerja kelompok. Berdasarkan hasil analisis pekerjaan siswa pada siklus kedua ini juga menunjukkan adanya peningkatan yaitu dari sekor rata-rata post tes 5,99 naik menjadi, 6,43 sehingga ada peningkatan 0,44 .

Pada siklus kedua siswa yang mendapat nilai 6 keatas ada 15 orang, dan siswa yang mendapat nilai kurang dari 6 ada 7 orang dari jumlah siswa 22 orang. Hasil tersebut masih belum sesuai dengan apa yang diharapkan. Pelaksanaan proses pembelajaran, guru kurang aktif membimbing siswa dalam mengarahkan setiap pesan yang ada pada beberan simulasi. Sehingga tanggapan - tanggapan siswa pada setiap pesan dijawab dengan jawaban kurang sempurna. Selain itu guru juga dalam penyediaan alat bantu yang berupa gambar-gambar sebagai penunjang dalam memberikan penjelasan materi untuk lebih meningkatkan pemahaman siswa dan pencapaian tujuan yang telah direncanakan masih kurang sempurna.

Selain itu peserta didik masih ada yang kurang menyimak pada pesan - pesan yang dibacakan oleh pemain utama simulasi, sehingga dia tidak memberikan tanggapan - tanggapan pada setiap pesan - pesan yang tertera pada beberan simulasi. Dalam hal ini guru segera ntemberi bimbingan yang positif terhadap siswa tersebut. Kekurangan lainnya adalah sesuai yang ditunjuk sebagai fasilitator, masih merasakan kesulitan dalam merumuskan kesimpulan kesimpulan dari setiap pesan - pesan yang tertera 


\section{Jurnal Ilmiah Pendidikan Scholastic}

pada beberan simulasi.

Siklus ketiga Pembelajaran pada siklus ketiga ini masih pokok bahasan yang sama, tetapi sub pokok bahasannya berbeda yaitu pelestarian sumber daya alam. Seperti halnya pada pelaksanaan kegiatan sebelumnya, yang dilakukan guru pada awal pelaksanaan siklus ketiga guru melakukan apersepsi dan membalikkan lembar soal pre tes. Setelah apersepsi dan pre tes guru memulai pembelajaran dengan membuka beberan simulasi yang ke tiga namun sebelum peserta didik bermain simulasi. terlebih dahulu guru memberikan penjelasanpenjelasan tentang pesan-pesan yang tertera pada beberan simulasi (beberan simuiasi ketikan siklus dapat dilihat pada lampiran). Pada waktu peserta didik bermain simulasi, guru membantu semua pemain utama termasuk membantu fasilitator dalam merumuskan kesimpulan - kesimpulan setiap pesan - pesan yang tertera pada beberan simulasi.

Setelah semua pesan - pesan tersampaikan simulasi diakhiri dengan pembacaan kesimpulan oleh fasilitator dibantu oleh guru. Pembelajaran dilanjutkan dengan pelaksanaan tugas kelompok yaitu menyelesaikan soal - soal yang tertera pada LKS. Pelaksanaan kerja kelompok tiap - tiap kelompok lebih aktif jika dibandingkan pada siklus pertama dan Siklus kedua Kerja kelompok diakhiri dengan pelaporan masing - masing kelompok. Dalam pelaksanaan evaluasi tampak peserta didik lebih serius. Hal ini ada peserta didik yang menyelesaikan soal - soal tersebut kurang dari 7 menit secara perolehan hasil evaluasi akhir yang pada umumnya cukup memuaskan, tapi sayang masih ada peserta didik yang menaapat nilai kurang dari 5 .

Refleksi Siklus ketiga Berdasarkan hasil analisis pekerjaan peserta didik pada siklus ketiga ini pada umumnya hasil belajar yang diperoleh peserta didik menunjukkan adanya peningkatan. Hal ini kita bandingkan dari skor 5,99, siklus kedua 6,43 dan pada siklus ketiga menjadi 7,12 dari siklus kesatu kesiklus kedua naik 0,44 dan dari siklus kesatu kesiklus ketiga 0,69 . Banyaknya peserta didik yang mendapat nilai 6 dan 19 orang dan peserta didik yang mendapat nilai dibawah 6 ada 3 orang jumlah siswa 22 orang.

Pelaksanaan kerja kelompok pada siklus ketiga menunjukkan hasil yang lebih baik jika dibandingkan dengan siklus kedua. Hal ini terbukti dengan adanya keaktifan siswa dalam menjawab soal-soal yang tertera pada LKS, antusias terhadap tugas yang diberikan juga kerjasama yang sudah cukup solid. Kesulitan yang masih dihadapi guru masih adanya siswa yang kurang tanggap pada suatu permasalahan yang sedang dibahas, sehingga secara berulangulang dibacakan lagi oleh guru hingga diberi penggarahan atau penjelasan yang mengarah pada jawaban permasalahan tersebut.

Saran perbaikan Kemampuan peserta didik dalam menganalisis suatu permasalahan yang tertera pada pesan-pesan simulasi, kemudian mendapat interprestasi dari hasil analisisnya memerlukan suatu pemahaman yang sungguhsungguh serta pengertian yang dalam mengenai pesan-pesan apa yang disampaikan pada suatu permasalahn yang berhubungan dengan IPS oleh kaena itu siswa harus memiliki kemampuan linguistik (kebahasan) yang baik dalam hal membaca pesan-pesan yang tertera pada beberan simulasi.

Dari hasil jajak pendapat di atas dapat di tarik kesimpulan bahwa respon siswa terhadap penerapan metode simulasi pada pembelajaran IPS pada prinsipnya sebagian besar siswa tertarik dengan alasan soal-soal IPS dapat diselesaikan jika permasalahannya betul-betul dipahami dengan jalan peserta didik harus lebih berminat dalam membaca IPS. Sedangkan tanggapan peserta didik mengenai belajar IPS secara berkelompok sebagian besar menyenangi terbukti dari 35 angket yang di sebar diatas (tidak hadir 2 orang), 19 siswa menjawab sangat menyenangi dan 12 siswa menjawab senang (sekitar 86,57\%) dengan alasan bisa mengerjakan soal - soal secara bersama - sama dan soal dapat diselesaikan dengan cepat.

Dan beberapa tanggapan siswa tersebut, jelas sekali bahwa belajar secara berkelompok dapat menumbuhkan motivasi peserta didik dalam belajar dan dapat mengembangkan sikap solidaritas yang tinggi antara sesama teman. Hasil wawancara peneliti terhadap peserta didik mengenai pembelajaran IPS dengan menggunakan metode simulasi jawabannya hampir semua peserta didik mengatakan sangat senang, ada juga peserta didik yang menjawab baik, bagus dan mengasyikkan. Alasan yang dikemukakan peserta didik, karena metode simulasi kita dapat bermain sambil belajar dan dapat berpikir secara kritis, dapat menghilangkan kejenuhan, menambah semangat belajar, lebih mengerti, bisa diskusi bersama - sama. 


\section{KESIMPULAN}

1) Sebelum menggunakan metode simulasi pada saat proses pembelajaran IPS, kurang dapat meningkatkan hasil. 2) Proses pembelajaran IPS dengan menggunakan metode simulasi dapat meningkatkan prestasi siswa kelas VI SDN No. 17 Batu Kunit Kecamatan IV Jurai Kabupaten Pesisir Selatan Tahun Pelajaran 2014/2015. 3) Proses pembelajaran IPS dengan menggunakan metode simulasi menyebabkan siswa lebih senang dalam belajar IPS. 4) Kelebihan dari penerapan metode simulasi dalam pembelajaran IPS diantaranya meningkatkan hasil pembelajaran, minat siswa kelas VI SDN no. 17 Batu Kunit Kecamatan IV Jurai Kabupaten Pesisir Selatan Tahun Pelajaran 2014/2015 yang tinggi, menghilangkan kejenuhan, menciptakan kegembiraan dan siswa belajar berpikir kritis dalam menghadapi suatu permasalahan. Sedangkan kekurangan metode ini diantaranya banyak menuntut imajinasi peserta didik yang terlibat dan memerlukan pengelompokkan yang luwes. Secara umum proses pembelajaran IPS dengan menggunakan metode simulasi dapat meningkatkan hasil dan mendapatkan tanggapan yang positif dari sebagian besar siswa kelas VI Semester Ganjil., SDN no. 17 Batu Kunit Kecamatan IV Jurai Kabupaten Pesisir Selatan Tahun Pelajaran 2014/2015.

Saran , 1) Adanya kelebihan dan kekurangan metode simulasi merupakan bekal bagi guru untuk selalu mempertimbangkannya dalam pemakaian metode simulasi. 2) Dengan adanya kekurangan yang dimiliki oleh metode simulasi, bukan berarti metode ini dapat ditinggalkan begitu saja. Metode simulasi dalam hal-hal tertentu akan sangat membantu terciptanya situasi yang menyenangkan dalam interaksi pembelajaran di kelas. 3) Buatlah perencanaan yang efektif dan efisien sesuai dengan tujuan yang diharapkan. 4) Sebelum pelaksanaan simulasi terlebih dahulu guru harus betul-betul membentuk kelompok yang luwes. 5) Pilihlah fasilitator yang kiranya benar - benar mampu untuk memimpin teman - temannya. 6) Guru harus menyediakan media pembelajaran yang sesuai dengan pokok pembahasan tersebut. 7) Berilah penjelasan pada setiap pesan yang tertera pada beberan simulasi. 8) Dalam merumuskan kesimpulan, fasilitator di bantu oleh guru.

\section{DAFTAR PUSTAKA}

Arbi, Z. S, dan Syahrun, S. ( 2001). Dasar Dasar Kependidikan, Depdikbud.

Depdiknas. (2003). Kurikulum Pendidikan Dasar, UU RI No 20 tahun 2003 tentang SISDIKNAS, Strategi Belajar mengajar (1991-1992), Metodik Khusus Pengajaran IPS (1995/1996).Jakarta.

Kasbolah,K, ( 2001), Penelitian Tindakan Kelas. Depdikbud.

Moedjiono, dan Dimyanti, M. ( 2001). Strategi Belajar Mengajar. Depdikbud Direktorat Pendidikan Tinggi Proyek Pembinaan Tenaga Kependidikan.

Moleong, J. L. (1996). Metodologi Penelitian Kualitatif. Bandung : PT Remaja Rosdakarya.

Rochmadi, W. N. (1997). Prosedur Pelaksanaan
Penelitian Tindakan Kelas, Jurnal pendidikan No.4 tahun XVI 1997.

Rusyan, T. A. (1996). Metode Pembelajaran. Jakarta.

Semiawan, C. (1992). Pendekatan Keterampilan Proses. Jakarta : PT. Gramedia Widiasarana Indonesia.

Sumaatmaja, N (1980). Metodologi Pengukuran Ilmu Pengetahuan Sosial. Bandung : Alumni.

Sumanti,M, dan Permana, J(1998 /1999). Strategi Belajar Mengajar. Jakarta : Depdikbud.

Syah, M (2002). Psikologi Pendidikan. Bandung : PT Remaja Rosdakarya.

Sukidin, et aL (2002). Manajemen Penelitian Tindakan Kelas. Surabaya : Insan 
Cendekia.

Tim Penyusun Pedoman Penulisan Karya Ilmiah. (2002). Pedoman Penulisan Karya Ilmiah. Bandung : Depdikna UPI.
Usman U. M (1996). Upaya Optimalisasi Kegiatan Belajar Mengajar. Bandung : PT Remaja Rosdakarya. 